\title{
A TRADABLE CONSERVATION EASEMENT FOR VULNERABLE CONSERVATION OBJECTIVES
}

\author{
W. WILLIAM WEEKS*
}

THE ISSUE

The critical conservation objectives in some conservation easements will probably be compromised by the effects of climate change in the relatively near future. Prompted to consider that likelihood, we can similarly predict that landscape fragmentation, invasive species, and other catastrophesanthropogenic and natural-may also seriously diminish the capacity of particular parcels of land to serve narrowly defined conservation purposes, and especially, the conservation of a particular element of biodiversity.

\section{II}

\section{CONSERVATION EASEMENTS, THE LAW, AND THE SCOPE OF THE PROBLEM}

\section{A. Introduction}

A fair understanding of the issue and the solution proposed here requires a quick, general look at conservation easements and the law that governs them.

Although there are real-property antecedents, such as equitable servitudes, of the now widely used real-estate interests we call conservation easements, specific recognition and authorization of conservation easements under the state property laws that principally govern them is a relatively recent phenomenon. ${ }^{1}$ For example, the Uniform Conservation Easement Act (UCEA), ${ }^{2}$ a form of which has been adopted in about half the states, ${ }^{3}$ was

Copyright () 2011 by W. William Weeks.

This article is also available at http://www.law.duke.edu/journals/lcp.

* Director, The Conservation Law Center; Adjunct Professor, Indiana University Maurer School of Law.

1. These laws range from Missouri's briefest of general authorizations, MO. REV. STAT. $\S 67.890$ (2010), to California's distinctive provisions that, like the federal tax code, specifies that conservation easements are to be perpetual in duration, but also provides that "the particular characteristics ... shall be those specified in the instrument creating or transferring the easement," CAL CIV. CODE §§ 815-816 (2010), to Nebraska's law, which requires notice to and approval by local authorities upon a holder's entering into and extinguishing a conservation easement, NEB. REV. STAT. §§ 76-2,112 to -2,113 (2000).

2. UNIF. CONSERVATION EASEMENT ACT (2007), available at http://www.law.upenn.edu/bll/ archives/ulc/ucea/2007_final.pdf 
completed by the National Conference of Commissioners on Uniform State Laws in 1981. The UCEA defines conservation easements as

\begin{abstract}
a nonpossessory interest of a holder in real property imposing limitations or affirmative obligations the purposes of which include retaining or protecting natural, scenic, or open-space values of real property, assuring its availability for agricultural, forest, recreational, or open-space use, protecting natural resources, maintaining or enhancing air or water quality, or preserving the historical, architectural, archaeological, or cultural aspects of real property. ${ }^{4}$
\end{abstract}

The UCEA "has the relatively narrow purpose of sweeping away certain common-law impediments which might otherwise undermine the easements' validity, particularly those held in gross." "That purpose could be and was effected with a model law comprising six short sections. UCEA-type conservation easements can be temporary or permanent and can be purchased or donated. They can be designed to serve purposes as broad and widely diverse as the above-quoted UCEA definition suggests: from air quality to preserving buildings of architectural distinction. ${ }^{6}$

Conservation easements broadly intended and drafted to serve those kinds of general purposes are, as a group, unlikely to be so acutely affected by changing ecological conditions that their broad purposes will cease, over time, to be served. If no easements were narrowly focused on the conservation of very specific conservation objectives, existing solutions in law to the occasional problem that did arise would be sufficient.

Further, existing law will generally offer adequate solutions when conservation easements are purchased or exacted. A conservation easement purchased or exacted by a governmental agency that ceases to serve the purposes for which it was acquired may be "released, modified, terminated, or otherwise altered or affected in the same manner as other easements," that is, by agreement with the owner of the restricted property. Before making such changes, however, the agency must observe governing law relating to the disposition of public property, including any specific restrictions on disposing of park-type property interests acquired for the perpetual use of the public. Also the agency may be constrained by government or donor restrictions on funds used in the transaction. ${ }^{8}$ A nongovernmental charitable organization that holds a purchased conservation easement that has ceased to serve its intended

3. Twenty-one states, the District of Columbia, and the U.S. Virgin Islands according to Legislative Fact Sheet-Conservation Easement Act,

UNIF. LAW COMMISSION, http://www.nccusl.org/LegislativeFactSheet.aspx?title=Conservation Easement Act (last visited July 31, 2011).

4. UNIF. CONSERVATION EASEMENT ACT § 1(1).

5. Id. at comm'rs' prefatory note.

6. Id. §1(1).

7. $I d . \S 2(\mathrm{a})$.

8. The surest course for achieving the flexibility to deal with unanticipated events in a purchased or exacted easement would be for the holder to negotiate for and document in the instrument the right to modify or terminate the easement. That kind of flexibility would not be permissible in an easement intended to qualify for tax deduction, as discussed infra Part II.C. 
purpose likewise has the option of seeking an agreement to terminate, but it also must consider, at least, the representations made in soliciting funds used to purchase the easement, as well as any restrictions on such funds.

What remains to discuss is the case of donated conservation easements, and in particular, donated easements that are, by their terms, intended to permanently conserve narrowly defined elements of biodiversity. That kind of conservation objective is likely to be affected by changes in an ecological context mediated by climate change or other byproducts of the modern human economy. ${ }^{9}$ For good reasons to be reviewed here, such easements are not easy to amend or terminate under either state law or relevant federal law. In a world in which ecological context is likely to change, it is a fair question to ask whether conservation easements are well matched to the biodiversity conservation job to be done. We might make them a better tool for conservation and for society by modestly reforming our view of what makes such easements perpetual.

Before describing that reformation, it will be useful to consider the limitations of currently available tools for responding to diminished effectiveness in donated easements designed to conserve vulnerable elements of biodiversity.

\section{B. Limitations on Flexibility Under State Law}

A first look at the law in UCEA states leaves many lawyers with the impression that the law provides for great flexibility in the administration of conservation easements. The language of UCEA $\S 2$, quoted above, regarding release, amendment, and termination seems clear enough, and it is apparently quite permissive. However, just as a government agency holding a purchased easement must observe not only the dictates of the UCEA, but also the law with respect to disposition of public property, it is fairly likely-not only in UCEA states, but in most states-that as the law develops, courts will determine that the holder of a donated conservation easement must observe the law of restricted gifts or charitable trusts when seeking to substantially amend or terminate that easement. ${ }^{10}$ This means that, if it proves impossible to continue to achieve the purposes of a donated conservation easement, the holder of that easement can seek to be released from the restrictions of the easement in a court proceeding under the doctrine of cy pres, which allows for modification of a charitable trust when its purpose becomes impossible, impracticable, or illegal to achieve. ${ }^{11}$ A court that agrees with the cy pres claim and releases the conservation easement holder from the fiduciary obligations

9. See, e.g., Climate Change-Health and Environmental Effects: Ecosystems and Biodiversity, U.S. ENVTL. PROT. AGENCY (June 10, 2010), http://www.epa.gov/climatechange/effects/eco.html.

10. The argument for this position is carefully developed in Nancy A. McLaughlin \& W. William Weeks, In Defense of Conservation Easements: A Response to The End of Perpetuity, 9 WYO. L. REV. 1 (2009). See also UNIF. CONSERVATION EASEMENT ACT $\S 3 \mathrm{cmt}$.

11. See, e.g., RESTATEMENT (SECOND) OF TRUSTS, § 399 (1959). 
originally associated with the restricted gift or charitable trust will require the application of the value thus freed up to an appropriately similar objective. A process is available in law, therefore, for responding when climate change renders easement-restricted land unable to serve the purposes of the easement. But, as I argue below, there ought to be an option to choose a different kind of easement: an easement that anticipates that a time might come when the restricted land is not the right place to conserve a particular rare species or natural community. The mutual choice of such an easement by donor and holder would qualify that easement for a streamlined set of procedures for responding if that time does come.

\section{Restraints on and Allowances for Flexibility in Federal Tax Law}

The federal tax law serves as a unifying law with respect to donated conservation easements. Not all donors of easements intend to take a federal income tax deduction for the charitable donation of a conservation easement. But donated conservation easement instruments tend to reflect quite closely the qualifying requirements of the federal tax code and Treasury regulations. ${ }^{12}$ One reason for this is that donors of conservation easements can carry forward unused portions of the available tax deduction. A donor who couldn't or didn't use the deduction in the year the donation was made might (with a proper and timely appraisal) be able to use the deduction in tax years to come. ${ }^{13}$ Also, when lawyers for easement donees review proposed conservation easements, they often refer to conservation-easement templates designed to meet federaldeduction requirements, because of certain protections built into the federal tax regulations (for example, mortgage subordination and the manner of handling reserved rights). ${ }^{14}$ The federal tax law of conservation easements, by contrast to the UCEA, requires that conservation easements intended to qualify for deductibility be perpetual. ${ }^{15}$

The Treasury Department has interpreted "perpetual" so as to accommodate the exceptional event of an unexpected and radical change in conditions. Treasury Regulation $\S 1.170 \mathrm{~A}-14(\mathrm{~g})(6)$ provides that if the change "can make" continued use of the property for conservation purposes impossible or impractical, the conservation purpose can still be considered protected in perpetuity "if the restrictions are extinguished by judicial proceeding" and the proceeds from sale or exchange are used by the donee organization in a manner consistent with the original conservation purposes. ${ }^{16}$

12. I.R.C. $\S 170$ (h) (2006); Treas. Reg. § 1.170A-14 (as amended in 2009).

13. I.R.C. $\S 170(\mathrm{~b})(1)(\mathrm{E}),(\mathrm{b})(2)(\mathrm{B})$ (LexisNexis 2011).

14. Treas. Reg. $\$ 1.170 \mathrm{~A}-14(\mathrm{~g})(2),(\mathrm{g})(5)(\mathrm{i})-(\mathrm{ii})$.

15. I.R.C. $\S 170(\mathrm{~h})(2)(\mathrm{C})(2006)$. Some have claimed, perhaps not entirely tongue in cheek, that perpetuity under the federal tax law means the statute of limitations for auditing the tax return of the easement donor. The easement holder's duties are however, not bounded by the same standard.

16. The parties to a conservation easement can and do, of course, make provision in advance to handle many issues associated with administration over time by including an amendment clause in the easement document. Such a clause, however, cannot allow amendments that compromise the 
This regulation, which establishes a cy pres-like standard for termination of conservation easements intended to qualify for a federal tax deduction, was promulgated at a time when most of us thought that if a conservation objective existed on a parcel of land today, it would likely exist there tomorrow and a hundred years from now. ${ }^{17}$ Most conservation objectives will stay put, and the impossibility or impracticality standard set forth for conservation easements in the Treasury Regulation cited above provides a sufficient escape valve for the odd cases in the generally stable group of conservation purposes. But rare species and rare natural communities are far less likely to be perpetually suited to the particular parcel in which they are found at the time a conservation easement is recorded.

\section{Current Law is not Well Suited to Moving Conservation Targets}

The cy pres-standard for relief likely to develop under state law, and now effectively applicable under federal tax law, is a demanding one, appropriately protective of the intention of the donor of the easement (and thus the promotion of charitable giving) and the federal tax subsidy-the deductionmade available for qualifying donations. Cy pres is not designed to be highly nimble or flexible nor calculated to facilitate optimum deployment of conservation resources. Moreover, modification of a conservation easement under this kind of standard involves a public and potentially adversarial proceeding; at least at the inception of the donated easement relationship, both grantor and donee typically express a commitment to permanently protect and defend the conservation values of public benefit that the easement is supposed to conserve.

That potentially adversarial proceeding may well be a catalyst for the public airing of differences in the motivation for and allegiance to the conservation restrictions in question. It may seem indisputable to an easement holder that if the principal conservation objective has been seriously compromised, there is no reason to continue to manage, enforce, and defend the easement, and it may seem clear that the resources bound up in the restrictions ought to be deployed where that conservation objective can be better served. Consider, however, the donor of a "perpetual" easement solicited by an easement holder because it

conservation purposes of the easement and still meet standards for federal tax deductibility. Thus, while one could draft an amendment clause for a conservation easement that would address the issue of climate mediated obsolescence because the likelihood of the event occurring is not small, see Treas. Reg. $\S 1.170 \mathrm{~A}-14(\mathrm{~g})(3)$, and because Treasury Regulation $\S 1.170 \mathrm{~A}-14(\mathrm{~g})(6)$ requires a judicial proceeding in connection with the extinguishment of restrictions, it may not be possible to draft such a clause and still preserve federal tax deductibility; one cannot amend away the implications of the perpetuity requirement of the Code, I.R.C. $\$ 170(\mathrm{~h})(2)(\mathrm{C})$.

17. E.g., Minor Tax Bills: Hearings Before the Subcomm. on Select Revenue Measures of the H. Comm. on Ways \& Means, 96th Cong. 243, 245 (1980) (written statement of Samuel W. Morris, President, French and Pickering Creeks Conservation Trust, Inc.) ("[S]hould rules be provided to take care of the remote contingency that at some time in the future a property subject to a conservation easement might cease to be used for that conservation purpose? We believe that with a well-planned easement program this is most unlikely to occur, but it is not impossible."). 
protects a narrow and specific conservation objective. It would not be at all unusual for that donor to have agreed to give the easement in part because she has a strong personal attachment to that particular parcel of land. Her conservation goal may be broad and general. The neighbors of the eased land may also have strong attachment to and appreciation of the open space conserved by the easement-restricted land. These attachments go beyond the narrowly stated conservation objective. When the narrow objective is no longer well-served by the eased land, it may well not seem evident to the donor and the neighbors that the easement has become a problem.

This difference in perspective may or may not present legal issues for the easement holder that wants court approval of a plan to redeploy its conservation-easement-bound resources. ${ }^{18}$ In many states various stakeholders could avail themselves of the services of the office of the state attorney general (who is often charged with the supervision of charities) to question the holder's decision to seek judicial amendment or termination of the conservation easement. $^{19}$

Even if it believes it would prevail if legally challenged, a nonprofit easement holder faced with differing views about what should happen to a conservation-restricted parcel of land that provides amenities other than the conservation of biodiversity will not consider terminating the restrictions before weighing public relations issues with implications for the fundraising objectives. For a government agency holder, such differing views can be the seeds from which front page news stories grow.

Under the law as likely to be applied to flexibility in conservation easements, then, there are real reasons that a holder of a donated conservation easement would be disinclined to commence the process of extinguishing even a poorly performing conservation easement on one parcel and reapplying the resources thus created to a parcel that better serves the intended purpose. Conservation resources are sufficiently scarce that it seems appropriate to consider an evolutionary advance in conservation easements that would, with appropriate safeguards, allow the parties to a biodiversity conservation easement to sign up for a slightly different kind of conservation relationship. This kind of easement would make it easier to secure optimum conservation effect from the scarce conservation resources available. It would also make it

18. In Illinois, for example, neighbors may have statutory standing to complain of the breach of the fiduciary duties of easement management. 765 ILL. COMP. STAT. ANN. 120/4(c) (West 2001). The standing of a donor who does not currently own the restricted property is more problematic. Compare Hardt v. Vitae Found., Inc., 302 S.W.3d 133 (Mo. Ct. App. 2009) (holding that donors do not have standing to enforce restrictions on charitable gifts) with Smithers v. St. Luke's-Roosevelt Hosp. Ctr., 723 N.Y.S.2d 426 (N.Y. App. Div. 2001) (holding that a donor does have standing to enforce restrictions on a charitable gift) for views on donor standing to enforce restricted charitable gifts.

19. An unhappy conservation easement stakeholder might be able to interest a state attorney general's office in exercising its charitable easement oversight responsibility. See RONALD CHESTER, George GleAson Bogert, \& GeOrge TAYlor BogERT, THE LAW OF TRUSTS AND TRUSTEES, § 411 (3d ed. 2005); UNIF. CONSERVATION EASEMENT ACT $\$ 3$ cmt. (2007). 
clear from the outset that all parties intend, should events compromise the service of the conservation objective on the eased land, to keep open their options for seeking to accomplish such objectives on another parcel of land.

\section{III}

\section{THE PROPOSAL, BRIEFLY}

To reiterate and expand upon a point made earlier, it is unlikely that land conserved for its outdoor educational value or its historic value or even its scenic value will be fatally compromised by climate change..$^{20}$ Nor will land conserved as open space be less valuable as open space because of climate change: even agricultural or forest lands are likely to be useable for some agricultural or forest purposes, though perhaps (as will often be the case aside from climate-change issues) not for the same use that prevailed when the easement was conveyed. But some easements (indeed those at the heart of the definition in federal tax regulations of "relatively natural habitat" $)^{21}$ meant to secure rare species or natural communities are fairly likely to be compromised by climate change, and as climate change occurs and the natural resilience of ecosystems is tested, are less likely to be able to resist other threats such as the effects of habitat fragmentation and invasive species. ${ }^{22}$

It may be useful, then, to allow land owners and conservation organizations to manage, in advance, the issue of responding to phenomena that affect the relative contribution of the easement-restricted property to natural-habitat conservation while dealing openly and consistently with the perpetuity requirement of the tax code, ${ }^{23}$ as well as the expectations of donors and neighbors. The goal of managing those issues in advance could be met by permitting donors and holders to choose a special kind of easement for the conservation of certain objectives that fit under the qualifying purpose of "relatively natural habitat." The new, special subspecies of conservation easement for these vulnerable elements of biodiversity might be called a Tradable Easement for Vulnerable Conservation Objectives (TEVCO). The general conservation objectives of the TEVCO would be the protection of rare species and communities that exist now on lands vulnerable to ecological changes. Because such species and communities occur in ecological contexts, their ability to persist over time on particular parcels of ecologically changing

20. The fate of easements protecting waterside land that may be compromised by rising water levels is beyond the scope of this inquiry; certainly the legal description of such easements will be important. The holder of restricted land that is inundated, or that eventually exists in theory on a seaside bluff is likely to have little to trade.

21. Treas. Reg. $\S 1.170 \mathrm{~A}-14(\mathrm{~d})(3)(\mathrm{ii})$ (as amended in 2009) (requiring a "habitat for rare, endangered or threatened species ... [or] natural areas that represent high quality examples of a terrestrial or aquatic community ....").

22. See U.S. EnVtL. PRot. AgENCY, supra note 9.

23. I.R.C. $\S 170(\mathrm{~h})(2)(\mathrm{C}),(\mathrm{h})(5)(\mathrm{A})(2006)$. 
land is doubtful. Rare species and natural communities with highly specialized habitat requirements will be particularly vulnerable.

The TEVCO would, in effect, be a specially permitted and exceptional way to satisfy the perpetuity standard of the tax code. The TEVCO exception would authorize an alternative means of permanently preserving both the biological and the monetary values bound up in the conservation purposes serviced by the conservation restrictions. Thus, perpetuity could be achieved not only by the permanent enforcement of the easement restrictions on the parcel of land to which they were first applied, but alternatively by the application of such restrictions and the monetary value associated with them to a different parcel of land on which the specified conservation objectives could be better achieved. TEVCO trading would not be inhibited by the laws of charitable trusts or restricted gifts because the TEVCO would specify, and the donor of a TEVCO would understand from the outset, that the purpose of the donation is to permanently pursue a specifically defined conservation objective (to protect a vulnerable rare species or natural community) wherever it can best be protected, rather than forever trying to preserve and defend that objective on the parcel of land on which it was originally protected. The form of the easement would permit neighbors, regional planners, and others to understand that the permanent conservation promised by the easement is not necessarily linked to a particular place on the landscape. The easement holder would have advance approval in an appropriate case to take the steps required to redeploy the monetary value linked to restrictions on land so as to serve again but elsewhere, as effectively as possible, the conservation objective. The path to doing so would (necessarily) not be entirely free of obstacles, but it would be reasonably clear and could be structured so as to minimize the likelihood of litigation in association with the decision to trade.

IV

\section{A FEW DETAILS}

\section{A. Perpetuity and Tradability}

In this special kind of tradable conservation easement, two things would be perpetual: first, the defined vulnerable conservation objective-the rare species or community-that met the requirements of the "relatively natural habitat" statutory purpose, and second, the real value of the conservation restrictions instituted to conserve that objective. A change in the conservation objective or purpose (even if the reason for the change is extinction of the species to be conserved) would still require the judicial process specified in Treasury Reg. $\S$ $1.170 \mathrm{~A}-14(\mathrm{~g})(6)$ (which would also satisfy the standards of a state that required a cy pres proceeding for such a change). Assuming, however, no change in conservation objective or purpose, the easement holder would be free under the 
laws of most states, ${ }^{24}$ and under the new federal tax provisions that authorized TEVCOs, to assess at their discretion the question of whether there was or would soon be a serious and long-term impairment in the conserved or restricted property's contribution toward the conservation objective, and to consider whether the objective could be better served on other available property. ${ }^{25}$

Besides clearly identifying itself as a tradable easement, sensible administration of a tradable easement policy requires that a TEVCO include a specific identification of the element of biodiversity the easement is intended to conserve. Trading would be limited to parcels on which that objective could be conserved. The "vulnerable conservation objective" of the tradable easement for vulnerable conservation objective is the rare species or rare natural community the easement was designed to protect under the tax code's broader qualifying purpose of conserving a "relatively natural habitat of fish, wildlife, or plants, or similar ecosystem." easement and conserved in a trade was the broad statutory purpose of protecting a "relatively natural habitat," one could trade a relatively natural habitat in Arizona for a relatively natural parcel in the Adirondacks. As an abstract matter, it could be argued that with appropriate documentation of the loss in effectiveness at serving the broad purpose in one place, and documentation of the high value of the relatively natural habitat in another, we should permit such trading because it will result in a national portfolio of TEVCOs that is optimized over time. But the Arizona-Adirondacks trade would require an apple-orange comparison of which objective evaluation is too problematic for at least the first iteration of the reform proposed here.

A TEVCO, therefore, would, at its inception, have to do what most relatively natural habitat easements under $\S 170(\mathrm{~h})$ do, and that is to specify the manner in which the "relatively natural" purpose is serviced. In a TEVCO, the easement would specify a "rare, threatened, or endangered species of fish,

24. As discussed infra Part III.F, in states using UCEA language, TEVCO perpetuity presents no problem: "[A conservation easement is] unlimited in duration unless the instrument creating it provides otherwise." UNIF. CONSERVATION EASEMENT ACT $\$ 2$ (2007). In the few states that require that conservation easements be perpetual, either the relevant statute would have to be revised to permit trading under TEVCO-type protections, or donors and holders would have to secure an authoritative interpretation of the law that accepted the liberalized interpretation of perpetuity suggested in this discussion. TEVCOs might require special authorization in states that require public processes in association with the extinguishment of conservation easements. See infra note 40.

25. A TEVCO that identified more than one primary conservation objective would be problematic; if one objective was well served by the restricted parcel over time, but another was compromised, a question arises as to the wisdom of permitting a trade. At the least, TEVCO trading rules would have to require that the successor parcel serve all originally named primary conservation objectives.

26. I.R.C. $\S 170(\mathrm{~h})(4)(\mathrm{A})(\mathrm{ii})$. At first impression one might be inclined to further define "vulnerable" by adding qualifications like "limited range" or "specialized habitat" to the federal description. It is not evident, however, that leaving the definition open to all rare species and communities would open the trading program to undesirable uses. 
wildlife, or plants," or a high quality example of a terrestrial or aquatic natural community as its "vulnerable conservation objective." 27

A TEVCO would, on the other hand, have to avoid doing what some relatively natural habitat easements do, which is to include as undifferentiated conservation objectives a broad description of the desirable natural elements present on the property to be conserved. (An expanded list of that kind could still be included in the easement and its conservation could be described as a secondary objective). Thus, an Arizona TEVCO might describe the conservation of federally threatened Chiricahua leopard frogs as a primary conservation objective (and, to make the point, a "relatively undisturbed northeast Sonoran desert plant community" as a secondary objective). A failing leopard frog TEVCO could only be traded for land in the Adirondacks if the Chiricahua frogs some day make the long trek north and east.

Constraining the trading opportunities in this way makes a TEVCO less flexible than a court might be in considering a petition for extinguishing an easement under cy pres standards. Such a court would be likely to find general as well as specific conservation intent in many easements. Upon agreeing to extinguish the easement it would be likely, therefore, to approve a proposed redeployment of the value previously bound up in the easement from one kind of high quality natural community to another. It could also be argued that broad categories of qualifying natural habitats lend themselves to a broader market for trading.

However, at the inception of a reform such as that proposed here-a reform that would permit trading without a priori review in a judicial proceeding-it seems reasonable for purposes of public accountability to restrict trading to easements and parcels that protect a primary conservation objective that can be easily understood to be the same. Limiting trading to parcels at which the same conservation objective could be served eliminates the need to assess the comparative conservation importance of the objectives of a proposed trade.

B. How Would a Trade be Accomplished?

Upon determining that another property could do more than the original property (or a successor restricted property) for the primary conservation objective, the holder of a TEVCO would be free to move the easement by

1. securing an offer of gift or sale of an easement over a new property which it has documented as a better property for the conservation objective;

2. securing an updated appraisal of the value of the restrictions on the property from which the restrictions are to be removed (referred to hereafter for convenience as the "original" property);

3. securing from the owner of the underlying fee of the original property an agreement to sell back the restrictions for an amount provided by the owner that is of no less value than the percentage of the current value of the property that corresponds to the

27. Treasury Regulation $\S 1.170 A-14(d)(3)($ ii) (as amended in 2009) includes a similar formulation as part of its elaboration of I.R.C. $\S 170(\mathrm{~h})(4)(\mathrm{A})(\mathrm{ii})$. 
percentage diminution effected by the original restrictions, or the updated appraised value of the restrictions, whichever is higher; ${ }^{28}$

4. notifying the state attorney general or other supervisor of charities of the state in which the property from which the restrictions are to be removed is located at least thirty days before;

5. carrying out a simultaneous closing in which the restrictions are released from the original property and placed upon the alternative property;

6. including provisions in the successor easement that are consistent with federal tax regulations applicable to conservation easements at the time of the trade;

7. placing any excess funds recovered in the sell back or new acquisition process in a restricted account to be expended solely on the acquisition of land or interests in land that contributes to the primary conservation objectives of the original TEVCO; and

8. reporting in detail any TEVCO trades or uses of TEVCO-restricted funds in its annual tax return if a private holder, in the federal register if a federal holder, and in a comparable public record if a state or local government holder.

\section{Approval and Oversight}

It is proposed that the holder of a TEVCO be empowered to make the judgments inherent in the standards requiring that the new property better serves the conservation objectives than the property being deaccessioned. That power is, of course, simply a different use of the power that the holder has under the law of most states and the law governing federally deductible conservation easements now; there is no provision for advance review of a holder or donor's judgment that a newly accepted conservation easement fulfills one of the statutorily established purposes. ${ }^{29}$ With the exception of a requirement that the holder report in detail on a trade in its tax return or on the public record for the year in which a trade takes place, and in every year in which any excess recovered funds are retained or expended, the mechanisms for oversight of the holder need not change from those currently in existence: holders are liable (though perhaps not likely) to be called to task for abuses by the attorney general of the state in which the restricted property is located. ${ }^{30}$ Nonprofit holders could be investigated by the IRS for failure to observe the

28. This standard is a slightly higher one, in that it also adds a call for a current diminution calculation, than the proceeds sharing standard set in Treasury Regulation $\S 1.170 \mathrm{~A}-14(\mathrm{~g})(6)$ (ii) for use upon extinguishment of a federally deductible conservation easement. That standard specifies a valuation "at least equal to the proportionate value ... at the time of the gift."

29. The law of Nebraska, as mentioned supra note 1, presents an opportunity for an as-applied exception. Thorough research on the law of all other non-UCEA states, as well as so-called Uniform Act states that have in fact heavily modified the UCEA, is beyond the scope of this discussion.

30. State attorneys general brought actions involving holders of conservation easements in, e.g., the Myrtle Grove case in Maryland, and in Salzburg v. Dowd in Wyoming. See McLaughlin \& Weeks, supra note 10, at 8 n.19. More generally, see CHESTER, BOGERT, \& BOGERT, supra note 19. As to the likelihood of state attorney general enforcement, see Ronald Chester, Grantor Standing to Enforce Charitable Transfers under Section 405 (c) of the Uniform Trust Code and Related Law: How Important Is It and How Extensive Should It Be? 37 REAL PROP. PROB. \& TR. J. 611, 628-29 (2003). 
requirements of the law with respect to a trade, or, in the case of truly egregious behavior, for failure to operate the charity exclusively for charitable purposes. ${ }^{31}$

Because built-in tradability provides both parties to the easement with a clear alternative to either being bound in an easement arrangement that no longer provides the benefits it originally did or undertaking a court proceeding under a cy pres standard, the risks of TEVCO abuse would actually seem to be somewhat lower than those associated with an easement in which TEVCO-type trading is not permitted; holders of poor performing conservation easements in the absence of a TEVCO option might be inclined to the position (as yet not generally discredited by judicial authority) that they could substantially amend or terminate conservation easements merely by agreement. Further, because of the streamlined path toward trading, the availability of the TEVCO option could also be expected to reduce the number of easements over time that suffer from holder neglect attributable to the ineffectiveness of such easements in serving their primary biodiversity-conservation purposes.

\section{Qualifying Circumstances and Duties}

It is the prospect of climate change that fuels this article's proposal for tradable conservation easements. However, the safeguards associated with the proposed transaction are sufficient to support trades in any situation in which circumstances have changed such that the conservation of a rare species or natural community has become difficult on a parcel restricted by a conservation easement if that vulnerable conservation objective can be better served on a different property that is available for trade. Everyone associated with the original transaction would have anticipated this possibility; the manner in which the new property would better serve the conservation objective will be documented and public, and the TEVCO would safeguard both the biological and the monetary value of the conservation objective for which the public provided a subsidy through the tax deduction. Thus, a TEVCO could be traded whenever a holder could meet the requirements for a trade, including, of course, the requirement that a deal be struck in advance for the conservation of land that offers a more secure or higher quality occurrence of the vulnerable conservation objective. ${ }^{32}$

On the other hand, because it is impossible to know in advance the full range of ecological and social issues associated with the release of a parcel of land from conservation-related restrictions, the holder of a TEVCO would be under no duty to seek to carry out a trade. To accomplish a trade, after all, the holder would need to secure some things not in its control (for example, a willing buyer of the restrictions and a willing seller of rights in a new parcel). And even if it could be proven that a restricted parcel was making a negligible

31. I.R.C. $\$ 501(c)(3)$.

32. For rare species and natural communities, there will by definition be a limited set of parcels that might be traded for. In the absence of a deal, the holder of a restriction in a parcel that serves the conservation objective poorly can of course fall back on the opportunity for relief through the courts. 
contribution to the conservation of a specified primary conservation objective, secondary conservation objectives, if broadly specified, are still likely to be served. It is both practical and justifiable to leave the holder free to allow the restricted property to remain in a conserved status. Beyond that, while acknowledging the utility of cautiously facilitating efforts to conserve the best land possible, one might justify a nod to inertia with the proposition that as a general rule, given the ubiquity of pressure to "develop" land, conservation in general is a public good (despite the reference in the regulations and in congressional commentary to "ordinary land," something one would be hard put to rigorously define)..$^{33}$

\section{E. Preliminary Thoughts About Drafting a TEVCO}

First, as suggested above, a TEVCO must specify the vulnerable conservation objective that serves the relatively natural habitat purpose. This objective would be expressly perpetual. Second, a TEVCO must specify that it is tradable, that is, that if the capacity of the land on which that objective is meant to be served is diminished, the holder may seek to move the restrictions-and the money-associated with protecting the rare element of biodiversity to a parcel of land that can serve the objective better. The possibility of a trade may, in some cases, make it more reasonable than it seems under current law to narrowly specify a primary conservation objective. Indeed, if the conservation objective of an easement is broad and durable, a standard conservation easement is a better choice than a TEVCO. The TEVCO option would exist to address a situation in which it is reasonably foreseeable that the conservation objective now served at a particular place may within a generation be better served in another place.

Also perpetual would be the provisions of the easement that set forth the management requirements for maintaining the biological health of the vulnerable conservation objective. It might be desirable, however, to permit the holder to unilaterally amend these provisions upon the occasion of a trade, if the science of conserving the occurrence at the time of the trade supports such amendments. This kind of amendment could, like TEVCO trades and uses of TEVCO-restricted funds, be one of the events to be described and explained in the holder's annual tax return or on the public record.

Some provisions of a TEVCO easement should not be perpetual, but should be expressly specific to a parcel or a circumstance. It should be clear that these provisions would not necessarily be included in a successor easement. Although conservation easements include some relatively generic provisions, a welldrafted easement also includes a number of customized provisions. Some such provisions relate to the long-term accomplishment of the conservation purposes in light of the particular characteristics of the restricted property; one could imagine, for example, an easement that prohibited row-crop farming on that

33. See Treas. Reg. § 1.170A-14(d)(iv)(B); S. REP. No. 96-1007, at 6747 (1980). 
relatively steep and erodible slope just above the sensitive food or host plant that a rare animal was expected to utilize. There may also be parcel-specific reservations or prohibitions that relate to specific activities taking place or likely to take place on the restricted property at the time of the original easement transaction.

\section{F. Few Changes to the Law are Required}

It is possible that TEVCOs could be authorized by Treasury Department regulations, but it would be preferable, at least (and, as will be evident, it would be hard to prevail in an argument with a Treasury lawyer who believed it essential) for Congress to provide statutory direction. The Treasury could execute that direction by developing specific regulations to guide donors and holders in creating and administering tradable easements for vulnerable natural-conservation objectives. The basic recognition of the desirability of a TEVCO could be codified in $\S 170(\mathrm{~h})(5)(\mathrm{A})$ by designating the current second sentence as (5)(A)(i) and adding the following as (5)(A)(ii):

Special Rule. In the case of a restriction granted on the use which may be made of real property for the purpose of conserving a relatively natural habitat under $\S$ 170(h)(4)(A)(ii), which includes a specific recitation of a conservation objective to conserve a rare, threatened, or endangered species of fish, wildlife, or plant, or a high quality example of a terrestrial or aquatic natural community, and which is entered into by donor and donee as a tradable easement for vulnerable conservation objective, and which contains provisions that allow release and re-assignment of the restrictions entered into to conserve the stated conservation objective, the restriction will be treated as perpetual if it contains provisions that require that in order to enter into a release and re-assignment of the conservation objective related restrictions, the donee must

(1) secure an offer of gift or sale of an easement over an alternative property which it has documented as a better property for the conservation objective;

(2) secure a qualified appraisal of the value of the restrictions of the original property, current to within 30 days of the proposed trade;

(3) secure from the owner of the underlying fee of the original property an agreement to sell the restrictions back to that owner at the percentage of the current value of the property that corresponds to the percentage diminution effected by the original restrictions, or the updated appraised value of the restrictions, whichever is higher;

(4) notify the state attorney general or other state official charged with oversight of charities operating in the state in which the property to be released from easement restrictions is located, at least 30 days before;

(5) carrying out a simultaneous closing in which the conservation objective related restrictions are released from the original property and placed upon the alternative property;

(6) include in the successor easement provisions consistent with the tax code and federal tax regulations applicable to tradable conservation easements the time of the trade;

(7) place any excess funds recovered in the sell back/new acquisition process into a restricted account to be expended solely on the acquisition of land or interests 
in land that contributes to the conservation objectives of the original qualified tradable relatively natural conservation easement; and

(8) report in detail any trades or uses of funds held under provision (7) above in its annual tax return or on the public record.

No other sections of I.R.C. $\S 170(\mathrm{~h})$ would have to be amended to accommodate TEVCOs; all other requirements of I.R.C. $\$ 170(\mathrm{~h})$ would apply to the TEVCO. Even so, because climate change, the immediate impetus for the TEVCO proposal, is met with skepticism by some in Congress, and because conservation easements have drawn attention recently for issues relating to valuation and fidelity to the qualifying conservation purposes, it might take a long time for Congress to take action on a TEVCO proposal. It is worth asking, therefore, whether TEVCOs could be authorized by regulation. The obvious first response is that if Congress does not act, Treasury surely should not act. But the question merits a second look.

The Treasury regulations interpreting I.R.C. $§ 170(\mathrm{~h})$ do not specifically anticipate climate change, but they evidence a clear awareness that stuff happens. As specified in Treasury Regulation $\S 1.170 \mathrm{~A}-14(\mathrm{c})(2)$, when a donee is faced with an "unexpected change in the conditions surrounding the property" that makes "impossible or impractical the continued use of the property for conservation purposes... [the donee] may sell or exchange the property" if the proceeds are used in a manner consistent with the original conservation purpose. This provision, obviously, could be called a precursor to the TEVCO proposed here. Two elements of the current regulations make clear the need for a more specific regulatory authorization: First, it might be argued that by choosing the general formulation "conservation purposes" the above-quoted regulation allows trade or exchange only when no qualified conservation purpose is served by the restricted property. Second, Treasury Regulation $\S 1.170 \mathrm{~A}-14(\mathrm{~g})(6)$, which also addresses the issue of changed conditions in conservation easements meant to qualify for federal deduction, permits restrictions to be extinguished only "by judicial proceeding."

Though TEVCOs would be on far firmer ground if supported by a change in the tax code applicable to conservation easements, the Department of the Treasury has, as indicated above, already determined, by regulation, ${ }^{34}$ that the statutory requirement of perpetuity ${ }^{35}$ can be satisfied if the original restrictions are adjudged impossible to achieve and are extinguished in a judicial proceeding, if the value of the extinguished restrictions is used to serve the original conservation purpose. From this standard, it is possible to discern current federal policy in the narrow area of failed or failing easements. The ultimate federal conservation-easement priority-the fallback position for the

34. The advocacy point to be made here in favor of authorization of TEVCOs by regulation is that theTreasury has already determined (Treas. Reg. $\$ 1.170 \mathrm{~A}-14(\mathrm{c})(2)$ ) that there is a need for it to clarify the meaning of "perpetuity" as used in I.R.C. $\S 170(\mathrm{~h})$ in certain situations, and that it has authority to do so.

35. I.R.C. $\S 170(\mathrm{~h})(2)(\mathrm{C}),(\mathrm{h})(5)(\mathrm{A})$. 
national investment in a conservation easement meant to be permanent-is the application of the assets bound up in a conservation restriction to the service of the original conservation purpose.

A Treasury Department willing to further refine its exceptional-cases definition of "perpetual" could make the TEVCO possible merely by adding language to Treasury Regulation $\S 1.170 \mathrm{~A}-14(\mathrm{~b})(2)$, which would then (additionally) read, "including a tradable easement for a vulnerable natural conservation objective as further defined in $\S 1.170$ A-14(c)(2)" or " $(\mathrm{g})(6)$." One of those two regulations, let us say $(\mathrm{g})(6)$, would include the following language: "[I]n the case of a conservation easement obtained for the qualified purpose of conserving relatively natural habitat under I.R.C. § 170(h)(4)(A)(ii), which specifies as a primary conservation objective the conservation of habitat of a rare, threatened, or endangered species of fish, wildlife, or plant, or a high quality example of a terrestrial or aquatic community, and which is expressly designed from the time of the original conveyance to be tradable, the requirement of perpetuity shall be satisfied as specified in Treasury Regulation $\S 1.170 \mathrm{~A}-14(\mathrm{~g})(\mathrm{x})$." And $(\mathrm{g})(\mathrm{x})$ would set forth the standards for drafting and trading a TEVCO. ${ }^{36}$

There is no evidence that Congress ever contemplated anything like satisfaction of the perpetuity standard by a succession of properties all fulfilling the conservation purpose, and at least one section of the Tax Code could be read to suggest that Congress anticipated easements and purposes that stayed put. $^{37}$ Even so, Congress has had ample time to express its disapproval of the Treasury regulations that provide for a reasonable exception, and has not done so. The TEVCO proposal is a variation (albeit a substantial variation) on the themes currently playing in the regulations. Perhaps in light of climate change, it is a particularly compelling variation. The vulnerable conservation objective of a TEVCO and the prescription for restrictions designed to conserve it would continue to be perpetual, as would the financial value bound up in the restrictions. The failsafe provision of the federal tax regulations, that is, the application of that value to the original conservation purpose ${ }^{38}$ is fully met by the TEVCO. Further, the purpose of securing the best relatively natural habitat for the nation would be better served. Thus, should Treasury decide to propose a regulation authorizing the TEVCO, it could reasonably claim that it was within its authority to do so, as well as arguing that the new regulation would serve the public interest.

With respect to state law, the UCEA states generally define conservation easements in a broad enough way to accommodate a TEVCO; the UCEA, as the Commissioners' Prefatory Note says, "allows great latitude to the parties ... to arrange their relationship as they see fit...." The patchwork of approaches

36. See supra parts IV.A, IV.B, and IV.F.

37. I.R.C. $\S 170(\mathrm{~h})(2)(\mathrm{c})$ ("[G]ranted in perpetuity on the use which may be made of the real property ....") (emphasis added).

38. Treas. Reg. $\$ 1.170 \mathrm{~A}-14(\mathrm{c})(2)$. 
that characterizes the law of non-UCEA states is too diverse to support an unqualified prediction that a TEVCO would be recognized as are other kinds of conservation easements in every jurisdiction. But, if the occasional perpetuity requirement is amended or interpreted as at its foundation linked to conservation purposes (more or less as the federal-tax-perpetuity requirement would, in this special case, have to be interpreted $)^{39}$ a quick review of nonUCEA state laws indicates that in the overwhelming majority of states the TEVCO would probably be recognized as readily as the kinds of conservation easements currently in use. ${ }^{40}$

G. Is Restricting Tradable Easements to Relatively Natural Habitats Justified?

Holders of outdoor-education and -recreation easements, open-space easements, and historic-preservation easements might fairly argue that the procedural safeguards associated with the tradable easements described herein are sufficiently rigorous that they, too, ought to be allowed to trade when they can upgrade. These holders might point out that they are no less able than natural habitat holders to decide whether land is optimally serving conservation objectives, and that they are no less able to understand the tradable easement choice.

Indeed, presuming the reform suggested here could be successfully administered for "vulnerable conservation objective-relatively natural habitat" easements one might, on balance, conclude that it is acceptable to open trading to all donated conservation easements originally obtained as tradable. Every easement donor would, after all, retain the ability to insist on an easement that could be extinguished only by judicial action and upon cy pres standards. At the outset, however, it is rare species and rare natural communities named as conservation objectives of relatively natural habitat easements that are most seriously threatened by climate change. And the health of biological elements protected in relatively natural habitat easements can be measured using more objective tools of assessment than the tools available for measuring the effectiveness of an open space or outdoor recreation easement. Thus, tradability is more compelling, and trades are more amenable to effective audit. Further, a wider spectrum of conservation goals is served by easements for open space and outdoor recreation or education. It seems sensible to restrict trading, initially at least, to relatively natural habitat easements that specify rare species or high quality natural-community objectives.

39. See supra note 24 .

40. A few states, as mentioned supra note 29, appear to require some government process in association with the termination of TEVCO-type easements. See, e.g., MASS. ANN. LAWS ch.184, § 32 (LexisNexis Supp. 2010); NEB. REV. STAT. AnN. § 76-2,113 (2000); N.J. STAT. ANN. § 13:8B-5 (West 2003); N.Y. ENVTL. CONSERV. LAW § 49-0307 (McKinney 2008) (as to “public” easements). 


\section{H. What About Amending Existing Easements to Become TEVCOs?}

TEVCO enthusiasts, should there ever be any, might argue that there are many conservation objectives already protected by easements that will surely be compromised by the effects of climate change. A change in federal law could allow for TEVCO deductions, but it would not change state law with respect to the facility or lack thereof with which existing easements can be amended; the federal law of qualified conservation contributions leaves many of the details of the law of recognizing conservation servitudes to the states. ${ }^{41}$ Perhaps, it might be argued, state laws should be amended to include provisions designed to eliminate obstacles to making those easements TEVCOs by amendment. Such an effort would face constitutional issues associated with the Contract Clause, ${ }^{42}$ and perhaps the state's constitutional provisions regarding separation of powers.

Whatever its vitality in the context of economic regulation of commercial contracts, the constitutional provision proscribing the impairment of contracts by state law lives yet in modern decisions in the context of charitable contracts. ${ }^{43}$ A state law designed to facilitate easement amendments allowing TEVCO trading would certainly be subject to challenge (assuming standing) for impairing the contract rights of donors who bargained for the usual provisions of a deductible easement: termination only upon impossibility and with judicial assent.

Such legislation might also breach state constitutional law with respect to separation of powers, by infringing on the province of the judiciary to consider changes in the administration of existing charitable trusts. ${ }^{44}$ This is so, to reiterate, because donated conservation easements need to be understood as being more than contracts between donor and holder. They are surely contracts, and subject to the law of contracts. They are also real estate conveyances, and subject to that body of law. They also are, it seems clear, charitable trusts, or restricted gifts (which are subject to the same judicial treatment as charitable trusts). ${ }^{45}$ The immediate parties are not the only beneficiaries of charitable trusts and gifts: the general public is also benefitted. Whereas the TEVCO rules would ensure the continuation of a public benefit, indeed, the primary express public benefit, the law that applies to existing charitable trusts and restricted gifts (including conservation easements that do not include a provision that allows for TEVCO type trading) requires more: the cy pres standard of impossibility and fidelity to the full set of substantive charitable restrictions typically present in a conservation easement.

41. Treas. Reg. § 1.170A-14(b)(2).

42. U.S. CONST. art. I, $\S 10$.

43. See McLaughlin \& Weeks, supra note 10 , at 88-89.

44. Id. at $89-90$.

45. Unif. CONSERVATION EASEMENT ACt $\S 3 \mathrm{cmt}$. See McLaughlin \& Weeks, supra note 10, at 20. 
State legislatures would be better advised not to attempt to authorize transactions involving existing conservation easements that would violate the donor's intent expressed therein that the conservation easement may only be terminated under extraordinary circumstances following a judicial proceeding.

\section{Who Would Re-Purchase TEVCO Restrictions? How Will TEVCOs Affect Public Perception of Conservation Organizations?}

Because there has to be a source of funds for the owner of the underlying fee to pay for the release of conservation restrictions, the likeliest circumstance for a TEVCO deal would be one in which there is an immediate demand for remunerative use of the property that is to be unrestricted. Certainly one could imagine an owner of an easement-restricted property having an interest in simply regaining the flexibility of owning or passing to heirs an unencumbered title, but the eager buyer would be one who saw immediate value in the deal. Think of the developer standing right behind the seller. Does that make the TEVCO a bad idea?

A trade could only occur if the holder of the TEVCO has made a deal to reapply the value of the restrictions to the conservation of a parcel that can be documented as better serving the original conservation objectives. Many of us cringe at the thought of development of the land once apparently conserved. Aside from that (and the holder is not ever required to make a trade) one might assert that it would be an ideal outcome if-consistent with donor expectations - the value of restrictions on land that has become a poorly performing conservation asset could be traded for a well performing conservation asset while the then-unrestricted original land becomes available for an economically valuable use.

When such a deal happens, someone is going to be unhappy; there is no avoiding it. But there is a short and honest response for that unhappy person: the land in question was conserved specifically for a named conservation objective, and the durability of that conservation status was always and publically dependent on the capability of that land to serve that named objective. Further, the public resources invested to secure that conservation status are preserved, and reapplied for the benefit of the original conservation objective. That answer should, for purposes of the reputation of the conservation community, be satisfactory to the band of the spectrum of public opinion that the pollsters call "persuadable."

\section{IV}

\section{CONCLUSION}

The TEVCO idea offered here for consideration can surely be improvedand may be shown to be unwise-by the questions the proposal will generate. The objective of imagining a TEVCO is to promote a useful reconsideration of the manner by which the law addresses change that compromises the capability of a particular parcel of land to service a defined conservation objective. A well 
considered innovation would facilitate the efforts of conservation easement holders to protect biodiversity as climate change affects it and would be consistent with the intention of the donors who choose it.

The TEVCO, as proposed here, would be a narrowly applicable but useful adaptation of the applied definition of perpetuity that currently characterizes federal tax regulations. That adaptation might also be a useful and reasonable one for those states that require conservation easements to be perpetual. The TEVCO would incorporate safeguards that would, in this special circumstance, represent an appropriate alternative to the path currently available to a holder seeking to optimally deploy resources bound up in a donated conservation easement of flagging utility.

Finally, there is a societal cost to encouraging conservation-oriented restrictions of land use: other socially valuable uses are foreclosed. The TEVCO offers a streamlined way for society to gain the benefit that justifies the cost. It could provide holders and donors with a quicker, more inviting, and yet sufficiently guarded path toward ensuring that land restricted for the purpose of conserving vulnerable elements of biodiversity actually does that job. 